\title{
SUPPLY CHAIN INVOLVEMENT IN AN ENGAGEMENT: VERIFICATION OF MARKETING AND OPERATIONAL COLLABORATION
}

\author{
Sumitro Sarkum ${ }^{1}$, BA. Pramuka², A.Suroso ${ }^{3}$, S. Suliyanto ${ }^{4}$, S. Sutarmin ${ }^{5}$
}

${ }^{1}$ Doctoral Graduate Programme in Management Science,

Economics and Business Faculty, Jenderal Soedirman University and Amik-Labuhan Batu, Rantauprapat-Indonesia 21421. email:sumitro.ulb@gmail.com

2,3,4 Deparment of Economic and Business Faculty, Jenderal Soedirman University, Karangwangkal, Purwokerto-Indonesia 53123.

5 Deparment of Economic and Business Faculty, Peradaban University, Paguyangan, BrebesIndonesia

\begin{abstract}
The ability of firm's market knowledge in relationships with employee engagement and customer engagement becomes crucial in a marketing strategy. However, the role of marketing function to achieve competitive advantage is still a question of improving business performance. Empirically, there is a need to explore marketing and operational capabilities by involving the supply chain in marketing strategies. Through the views of Dynamic Capability (DC) and service logic, we combine it in a conceptual model that produces several hypotheses. A total of 250 MSME (Micro Small and Medium Enterprises) are involved to answer the questionnaire. Respondents' perceptions reveal that the supply chain has essentially opened itself into an engagement for mutual value creation and sustainability. Our findings also reveal that supply chain engagement can improve business performance and positively mediate employee engagement, but it is unable to mediate customer engagement. In contrast, supply chain engagement is insignificant when market knowledge, customer engagement and employee engagement are directly linked to business performance. In addition, our findings also resulted in an insight for management in optimizing the firm's ability to perform its marketing functions.
\end{abstract}

Keywords: business performance; competitive advantage through engagement; market knowledge, supply chain; structural equation modeling

\section{INTRODUCTION}

The idea of the Dynamic Capability (DC) theory is still an interest of researcher until now. It is deeply influenced by the views of economic evolution by Helfat \& Peteraf (2003); the idea of technology by Lavie (2006); and the idea of management innovation by Teece, Pisano, \& Shuen (1997). Nevertheless, in recent years the idea of Dynamic Capabilities (DC) theory has been much discussed by researchers, especially on marketing perspectives that have spawned the new term of Dynamic Marketing Capabilities (DMC's). This is stated in a review of literature conducted by Barrales-Molina, Martínez-López, \& Gázquez-Abad (2014) which 
states that one significant problem occurs in the development of Dynamic Capability (DC) is the role of marketing function to performance. Likewise in the information of Storbacka, Brodie, Böhmann, Maglio, \& Nenonen (2016) explain that the micro foundation movement (eg D. J. Teece, Pisano, \& Shuen, 1997) is seen less explanatory in relation to the company's performance levels. In contrast to the findings of Tan \& Sousa (2015) which suggest that Dynamic Capability (DC) theory is an important determinant factor in the firm competitive advantage and performance (Fang \& Zou, 2009). In addition, the success of the firm's business is also seen as a sustainable competitive advantage involving the value chain of retail and supplier collaboration (Berning \& Venter, 2015). In addition, the role of suppliers in the supply chain is crucial to bridge buyers and suppliers as a process of customer relationship management (Duffy, Fearne, Hornibrook, Hutchinson, \& Reid, 2013). There is a need for collaborative marketing and operations to integrate market knowledge as a dynamic capability of the company into the supply chain (Barrales-Molina, Martínez-López, \& Gázquez-Abad, 2014). Therefore, it is necessary for the participation of middle managers in the planning process to identify potential business and relevant supply chain to become information in the marketing strategy's decision ((Darkow, 2014). Based on the explanation and understanding of the dynamic capabilities and engagement described above, we argue that dynamic marketing capabilities are a portfolio of dynamic capabilities engage to the social relationships of management to customers, employees and the supply chain in the competitive advantage context as company's performance goals

\section{THEORITICAL BACKGROUND}

\section{Market Knowledge}

According to Simard (2006) the definition of market knowledge is a group of value chain service knowledge relationships that function to collectively instill, promote, and extract value driven by organizational capacity to supply user demand as knowledge service. The essence of market knowledge is a mechanism to enable, support, facilitate and mobilize, share, or exchange information and knowledge between providers and users. The main focus of the market is to connect the two to formulate the way out of the problem with the right people and this is a transactional approach that assumes knowledge-based products or services are available to be distributed to someone who wants to use them (D Tapscott \& Williams, 2008). Such perspectives are most appropriate when there is no control over the production or use of exchanged content as it does in the perspective of providers and users who appear in social networks to succeed in the digital market (Don Tapscott, Ticoll, \& Lowy, 2000). Changes in 
competitive order and rapid global competition also require companies to develop dynamic capabilities by creating and combining resources that are difficult to imitate globally as a competitive advantage.

\section{Competitive Advantage through Engagement}

\section{Customer Engagement}

Kumar et al., (2010) revealed that assessing customer value based solely on transactions with firm itself is not sufficient and it is important to appreciate customer engagement to avoid overvaluing customer ratings. Involve customers and develop engagement to provide information directly from customers and have greater influence to increase sales (Barth, 2007). Changes in technological globalization progress, sophisticated customers, excessive demands, unhealthy competitive climate and financial crisis within a country are some shifts in the business environment. The speed of information, new innovations and opportunities to create diverse choices create new problems for companies to retain customers (Carter, 2008). In the global economic order, the level of competitive pressure requires companies to invest more time and resources in innovating. It was investigated by Cambra-Fierro, Melero-Polo, \& VázquezCarrasco (2013) to take a closer look at customer engagement as a non-technical innovation related to the commercial marketing and process capabilities of 176 mobile telecommunications companies in Spain; They found a new approach to customer portfolio management to increase customer satisfaction and loyalty that led to a commitment to spread positive word-of-mouth; And the emergence of the attachment manifestation significantly improves the performance of firms that encourage non-transactional behavior among customers. The findings are in line with the theories proposed by Kumar et al., (2010) and Doorn van et al. (2010) thus companies should change their approach to customer portfolio management and embark on investing more on more analytical models that take on behavior Transactional such as repurchase intention becomes one of the considerations. Further J. Cambra-Fierro, Melero-Polo, \& Javier Sese (2015) offer new insights into service research that can help researchers and managers better understand non-transactional customer behavior to deal with complaints that not only increase customer satisfaction But also customer engagement; and proper management of the problem handling can make customers more engaged. So far it can be seen that researchers have sought to understand empirical engagement that go beyond purchasing and the level of interactions between candidates and customers who are connected to a company's brand by engaging others in the brand-created social networks, offers and individual activities involved from customers and potential customers. In the 
discussion and implementation in Vivek, Beatty, Dalela, \& Morgan (2014) explain that engagement can also be seen as a way to create customer interaction and participation.

\section{Employee Engagement}

Kahn (1990) found that there are three psychological conditions associated with engagement or disengagement at work; significance, safety and availability. In other words, workers are more engaged to the workplace in psychological situations that offer more significance to them, psychological security and when they are more psychologically present. In the definition of Kahn (1990) employee engagement feels obliged to bring themselves more into their performance role as payment for the resources they receive from the organization and when the organization fails to provide this, the employees individually tend to attract and detach from their roles. Thus, the amount of cognitive, emotional and physical resources an individual is prepared to devote to the job performance role of someone who depends on the economic and socio-emotional resources received from the organization. A precious conclusion poured by Macey \& Schneider (2008) that companies that have gained employee engagement with the right conditions will be very difficult to imitate by competitors and become a key competitive advantage of the company (Sundaray, 2011). While Devi (2009) states that in today's competitive environment, companies must ensure in philosophy and practice, they recognize the importance of managers in retaining employees. A highly bonded workforce is a sign of a healthy organization, regardless of size, geographic location and economic sector. Rothmann \& Rothmann Jr (2010) revealed that there are two psychological conditions that make the employees engaged, namely the meaningfulness and availability psychology which is based on the role of fit job and a positive job resources (B. Shuck, Reio, \& Rocco, 2011). While the growth opportunities of the organization become the spirit, dedication and absorption of attachment (Stander \& Rothmann, 2010). In addition to the need for employee development, leadership development is also needed to demonstrate empowerment behavior (Van Schalkwyk, Du Toit, Bothma, \& Rothmann, 2010; Romanou et al., 2010). In the M. B. Shuck, Rocco, \& Albornoz (2011) article that examines the unique experience of engaged employees in their work that finds the development of relationships and engagement to colleagues, the climate and opportunities for learning require the direct role of managers in shaping the bound employee interpretation of the work (J. Xu \& Thomas, 2011; Andrew \& Sofian, 2012). The question is, how can marketing play an important role in extracting the crucial value of construction management?. To answer that question, Kumar \& Pansari (2014) discuss employee engagement impacts through literature review, insight interviews from managers 
across five continents, define the definition, scaling, debating how to improve company performance and after going through the whole process they find satisfaction, commitment, loyalty and performance of employee, positive interdependence that affected employee engagement in accordance with the literature.

\section{Supply Chain and Business Performance \\ Supply Chain}

It is important for a sustainability oriented organization to see the retail and supplier value chain in a collaboration to instill sustainability efforts (Berning \& Venter, 2015). Initial supplier engagement, in this case in line with Saunders et al. (2015) is as the organizational supplier's engagement in conceptual and planning activities. The positive impact of supplier engagement in the design phase on financial performance has been widely discussed in the new product development literature (Ragatz, Handfield, \& Scannell, 1997; Primo \& Amundson, 2002; Petersen, Handfield, \& Ragatz, 2005) and particular sustainability (Hong C. Zhang, Kuo, Lu, \& Huang, 1997; Walton \& Handfield, 1998; Hong C. Zhang et al., 1997). Engagement is also connected and involving stakeholders in the process (Rantavaara et al., 2005). Umar \& Chawaguta (2014) say that the benefit of strong engagement of stakeholders representing different perspectives, types of skills and health of supply chain management. Environmental management becomes an important topic in supply chain management, little practical and theoretical understanding of how companies (supervisory support, rewards and training) relate to employee engagement in environmental behavior. Most supply chain management research focuses only on the ideal situation of producer engagement with all downstream partners. Given the high costs, the lack of trust or incompatibility of electronic data processing systems to help small and medium companies reveal the possibility of advantages and disadvantages in the process that arise with the various number of subscribers than specified by the reorder on the inventory management system or the cooperation forecasting and replenishment planning as stated in the objective value. The use of internet and related services creates interactive work for the user to be possible, whenever, wherever and with anyone. Increased e-Business transactions become significant in sharing the information primarily in supply chain management. Attaran \& Attaran (2007) concludes that collaborative practice of supply chain management especially in the cooperation of forecasting and replenishment planning firmly is the next path to successful and sustainable business operations. Improving supply chain effectiveness through demand planning, production scheduling synchronization, production planning, logistics planning and new product design will force suppliers to innovate and build 
strong relationships with each other by encouraging smarter ways to take action (Kannabiran, 2009). Most of the supply chain engagement in an ongoing context lie in a dynamic environment and lead to the assumption that supply chain management requires the adoption of dynamic management (Beske, 2012).

\section{Business Performance}

There are two different aspects of business performance: product-market performance and financial performance (Morgan, 2012). According to Morgan (2012) market-product performance concerns the customer buying behavior responses and prospects in target markets to realize the company's position in customer advantage. Furthermore, perceptions are enhanced by changing customer buying behaviors in ways that benefit the company. If everything is the same, it improves the performance of market products in ways that can be captured by indicators, such as; greater sales volume, improved customer satisfaction and loyalty behavior, lower price sensitivity and growth of the company's market share. Or the company realizes the cost of profits by choosing to provide the offer equals to stock value and strive to maintain existing perceptions and buying behavior patterns between target customers while enjoying a greater profit than the same selling price as competitors. Morgan, Clark, \& Gooner (2002) explain that market performance concerns market awareness and reactions to profit is aware of the position achieved. This can be seen from customers, competitors and internal perspectives. From a customer perspective, market performance involves cognitive and effective responses (e.g. brand awareness and quality perceptions) and subsequent behavioral consequences (e.g. decision making on purchases and actions) of the prospect of customers in the target market to realize the profit positions achieved by the firm. From an internal-oriented perspective, market performance manifests itself in the subsequent effects of customer behavior as seen in unit sales and sales revenue. From the competitor's perspective, market performance is seen in the indicator of that as part of the mind and market share. From a normative perspective, an assessment of marketing performance involves the assessment of marketing resources and capabilities as a source of profit, profitability of position achieved, market performance from customer perception through customer behavior to post-purchase customer and sales unit, market share and others. (Company perspective), while in the financial consequences (income, cash flow, and profits). The time required between obtaining a source of profit, achieving a profit position, improving market performance and a major impact on the financial results observed, it may differ significantly among industries. The changing of competitive maps is based on the concerns about the sustainable natural environment as a 
business issue predicted by Leonidou, Katsikeas, \& Morgan (2013) due to the role of green marketing programs in influencing the company performance, weak resources and risk aversion of top management on the deployment of program as well as the effect that suggests supporting such relationship. It was revealed that the green marketing program being implemented by the company found evidence of performance on significant salary payments, specifically that the product and distribution of green marketing programs positively affected the market performance of product, while price and promotion directly related positively to the return of company assets. In addition, the industry's environmental reputation level moderates the relationship between green marketing programs and the company's product market and financial performance. On examination of the market effect of overflowing products from investment management activism on the target of industrial competitors by Aslan \& Kumar (2016), it turns out to be negative and shareholder wealth has an effect on the average of the company's competitors. The effect on the market performance of competing products is commensurate with post-activism improvement in productivity, efficiency cost and target of capital allocation, and product differences. The effect is observed on the performance of competing product markets as measured by profit margins (raising or lowering prices) and market share, operations and capital investments.

\section{HYPHOTHESIS DEVELOPMENT}

Initiating this research on the extent to which supply chain involvement affects business performance, we propose the research model presented in Figure 1, and the construct is formally defined in Table 1.

\section{Market Knowledge and Competitive Advantage through Engagement}

In a competitive business environment, market knowledge is the key to success that differentiates companies from others. In the process, companies need a dynamic ability to cope with change to understand what customers want and offer (Augier \& Teece, 2007). Market knowledge allows companies to establish open market space mechanisms with the help of networks from customers to facilitate companies and communities to coordinate with each other (Verhoef, Reinartz, \& Krafft, 2010). Integrating knowledge into products that are then exchanged with customers in a market is the result of the company's sensitivity to behaviors and issues that affect the buying interest of customers (Sumitro, 2016). Customers are a source of information, developers who can work together and innovators in the market. Thus, companies can transfer customer knowledge by bringing customers closer to a development 
process that involves their knowledge directly in each stage (Cui \& Wu, 2015). Market knowledge refers to the company's knowledge of customer needs and behaviors, as well as competitors' behavior. It is the result of a systematic process of organizational market information, including acquisition, interpretation, dissemination, and represents the cognitive maps of a company's customers and competitors. Bao et al., (2012) defines broader market knowledge as the scope and diversity of corporate knowledge about customers and competitors. In the business market, working with customers and users is increasingly becoming essential to gain knowledge of needs and to develop new products. Based on the relationship between market knowledge and customer attachment, it can be depicted a hypothesis as follows: H1a: Market Knowledge positively affects Customer Engagement

The payment of employee knowledge through satisfaction for getting salary and job engagement, give the organization an opportunity to create value propositions of employee satisfaction and improve employee engagement. Knowledge performance is positively related to pays satisfaction and, in turn, organizational effectiveness contributes to higher work engagement. However, payroll compensation for the knowledge held is influenced by the firm's market activities (Mulvey, LeBlanc, Heneman, \& McInerney, 2002). A company must reward the value of knowledge possessed by its worker as stated by Bogdanowicz (2002) which states that in a newly developing economy, millennium knowledge is an asset to be valued, developed and managed, as it is a component of the intellectual asset of a Organizational data and information help maintain a competitive advantage. Knowledge is an intangible asset and to manage it creates a number of challenges in the field of human resource development, especially when workers are more concerned with their work. Linking market knowledge to the company's market orientation and company's environmental performance in environmental strategies, employee engagement with product quality as stated by Y. Chen, Tang, Jin, Li, \& Paille (2015) to 134 CEOs, marketing managers and front-line employees at companies in China found that market orientation positively affected environmental strategies that in turn affected the products quality environment and employee engagement environment. Applying a future strategic developmental approach on employee by creating market knowledge embodied in company' strategy in the face of exponential time changes, resulting in volatile and emerging new markets based on rapidly evolving technologies, requires competence, intellectual assets and the relevance of the company's physical resource skills is an implementation to generate competitive advantage (Darkow, 2014). Whereas for maintaining a competitive advantage, companies need to do various ways and one of them is by innovating services to create company value. Research on service innovation and market-fit capabilities 
connect market and market turbulence in the form of a relationship between service innovation and new product performance of 170 service-based firms studied by K.-H. Chen, Wang, Huang, \& Shen (2016) show empirical results that new product performance is highest in situations involving high-levels of service innovation, market-linking, and market turbulence. Therefore, the ability to connect the market can generate superior market knowledge and in turn, is identified as a key resource associated with the firm's ability to respond to markets and ensure profit growth. The ability to connect markets is considered an important capability that should take into account the involvement of companies in service innovation, not only to enable these companies to respond quickly to changing market trends and customer needs, but also to assist them in obtaining timely information that can be directly utilized for development of new products / services. Based on the relationship between market knowledge and employee engagement, it can be depicted a hypothesis as follows: H1b: Market Knowledge positively affects Employee Engagement.

Creation of market knowledge and partner engagement in the supply chain as an interconnected operational efficiency in the process of information sharing as the creation of new knowledge, in the organization's efforts to acquire, assimilate, transform, and exploit knowledge to produce dynamic organizational capabilities. Malhotra, Gosain, \& Sawy (2005) argue supply chain partnerships are a type of inter-organizational partnership whose primary goal is to coordinate business processes around the exchange of goods and services, demonstrating operational efficiency and the creation of market knowledge that can be achieved in this type of supply chain partnerships. Mazdeh, Akhaven, Jafari, \& Mousavi (2014) reveal that much earlier than the existing literature studied the design of supply chain engagement on supply chain layout modeling as a result of or in connection with product design (Lamothe, Hadj-hamou, \& Aldanondo, 2006) and organizational designs that supports factoring in packaging design into product development packages (Klevas, 2005). Therefore, through effective supply chain engagement, firms are more likely to integrate and absorb specific knowledge in the supply chain quickly and effectively. Feng \& Wang (2013) research show that positive internal engagement is related to customer and supplier's engagement. In particular, the most important internal engagement in improving the velocity of new product development, while customer and supplier engagement have significant effect on the cost of developing new products and the velocity of new product development. In addition, internal and customer engagement improves market performance indirectly, while supplier engagement improves market performance both directly and indirectly. Kanapathy, Khong, \& Dekkers (2014) prove that supplier involvement practices have a significant positive impact on new product development 
project performance in an emerging economy with respect to quality objectives, design objectives, cost objectives, and 'time-to-market' objectives. While Feng \& Zhao (2014) study of 176 manufacturing companies in China found that top management support enhances relationship with customer and supplier. Relationships with customer increase the level of customer engagement, while relationships with suppliers increase supplier engagement levels. The development of new products is important for manufacturing firms to compete in the market. This is especially true in a transitional economy where dynamic markets and firm technologies require change to co-create value with customers and suppliers. Based on the relationship between market knowledge and supply chain engagement, a hypothesis can be depicted as follows: H1c: Market Knowledge positively affects Supply Chain Engagement

\section{Competitive Engagement}

The development of global markets growth is increasingly efficient and business competition is increasingly conical. Collaboration is the company's choice to achieve competitive advantage. Customer-supplier engagement differs across sectors and so does the supply chain process. It is important to involve customers and suppliers in demand management, product development, transportation, and inventory; although sometimes suppliers and customers are less involved in the process by the company (Sahay, 2003). The purpose of supply chain management is to meet customer needs (Chow et al., 2008). As with the simulation model by Thron et al. (2006) to evaluate the distribution framework of food producers and customers show that producers and consumers substantially benefit from a partial increase in demand visibility. Likewise with the findings Kannan \& Choon Tan (2006) which show the engagement of customers and suppliers have a positive effect on the success of both relationships that can improve firm's performance. The purpose of such a relationship is to mutually provide benefits with buyers and suppliers. From the buyer's point of view, this comes in the form of exploiting resource enhancement, strategic focus and ability to leverage supplier skills and capabilities. It is to manifest itself in improving product quality and competitiveness which in turn drives the market and financial performance. While there is an inherent logic behind the relationship between successful relationship and performance, until now there has been little empirical evidence to support it, therefore the outcome is significant. Singh \& Power (2009) study used data from 418 factories in Australia, the result of structural equation modeling analysis showed that customers relations and suppliers involvement influence firm performance. The results of this study provide insight into how the company can develop the level of collaboration capability. Danese \& Romano (2011) suggest that to optimize performance efficiency requires 
requires levering simultaneously on customer and supplier integration to foster their interaction, rather than investing and acting on customer integration only. In addition, before deciding whether to invest in customer integration, managers should ascertain the level of supplier integration, since it acts as a prerequisite for the successful implementation of customer integration. The implications are based on the results of regression analysis showing that supplier integration positively moderates the relationship between customer integration and efficiency. In integration with both internal and external contexts (customers and suppliers) and their relationship with customer satisfaction and its impact on financial performance, $\mathrm{Yu}$, Jacobs, Salisbury, \& Enns (2013) demonstrate that internal integration significantly influences both dimensions of external integration (customer and supplier integration ); and that supplier integration is significantly and positively related to financial performance. While integration impacts new product development, Y. He, Keung Lai, Sun, \& Chen (2014) stated that supplier integration has a positive impact on customer integration through the mediation role of manufacturing flexibility. As for integration motifs into alliances, Siew-Phaik, Downe, \& Sambasivan (2013) find the key differences in strategic alliances with suppliers and customers are: the relationship between the environment and alliance motives is stronger for alliances with suppliers, the relationship between alliance motives and relational capital is significant for alliances with customers, the relationship between asset specificity and interdependence is significant for alliances with customers, and the relationship between perception of opportunistic behavior and relational capital is significant for alliances with customers, and the relationship between perception of opportunistic behavior and interdependence is significant for alliances with suppliers. Based on the relationship between customer engagement and supply chain engagement, it can be depicted a hypothesis as follows: H2: Customer Engagement positively affects Supply Chain Engagement.

Some research on employee engagement and its relationship with supply chains such as Harland (1996) suggests that the soft features of behavior such as attitudes, engagements, expectations, and perceptions among supply chain partners are crucial to the success of partnership. Croxton, García-Dastugue, Lambert, \& Rogers (2001) and Skjoett-Larsen, Thernoe, \& Andresen (2003) agree that supply chain management requires the engagement and coordination of activities within the organization and among partners in the supply chain. III \& Tallon (2003) found that management and employee engagement can improve supplier partnerships. Vanichchinchai \& Igel (2011) say that human resource management and engagement are essential in implementing supply chain management. Further Vanichchinchai (2012) study found that employee involvement has a direct positive impact on partnership 
management. The internal employee involvement in Total Quality Management (TQM) leads to improved management of external partners in supply chain management. In addition, employee involvement has a significant direct effect on firm's supply performance. Employee involvement also has a significant indirect effect on firm's supply performance through partnership management. Although supply chain management emphasizes external partnerships with customers and suppliers, the implementation of supply chain management should manifest starting from internal collaboration between departments and employees. This confirms that effective employee engagement is important in enhancing partnerships in supply chains and supply performance. The employee's perspective should be changed from the perspective of negotiating power to a collaborative perspective. Employees may reject supply chain partnership initiatives if they do not clearly understand the benefits of the initiative, or feel that they will be negatively affected. Therefore, the reason for communicating about skills initiatives and training for new supply chain management techniques should be provided. Such programs should be offered to employees within the organization and extended to external business partners as well. Supply chain managers should not only focus on operational issues or external partnerships but also should emphasize employee internal issues gently. On the reciprocal relationship between different dimensions of supply chain integration to explain performance measures (flexibility, delivery, quality, inventory, and customer satisfaction). Alfalla-Luque, Marin-Garcia, \& Medina-Lopez (2015) showed that the relationship between employee commitment and operational performance is fully mediated by supply chain integration. Employee commitment contributes to improving internal integration, and internal integration affects performance both directly and indirectly. Moreover, obtaining internal integration helps to achieve supplier and customer integration. As a result, companies should strive to achieve both employee commitment and internal integration, as they mutually reinforce each other. Similarly, managers should achieve internal integration before external integration and include external integration at the strategic level in order to reap the greatest advantages from supply chain integration. Meanwhile, managers should promote employee commitment not only for better supply chain success, but also to mitigate the barriers of supply chain management implementation. In the process of supply chain integration required a good relationship of the role of employee engagement to generate performance benefits for the company. In the context of attachment, the role of organizational culture is crucial to the relationship of both. The organization's success underpinned by human resource development, teamwork, employee commitment, and caring for others aims to go beyond and win the competition in a competitive marketplace. In the study of Yunus \& Tadisina (2016) of 223 
Indonesian-based manufacturing firms indicate that the relationship of supply chain integration and firm performance is positively influential, and organizational culture positively affects the relationship between supply chain integration and customer orientation. Employee engagement is essential to encourage them to share information and identify barriers in the integration process with supply chain partners. Some researchers show and support that employee participation can enhance supplier and customer integration (Shub \& Stonebraker, 2009; Sweeney, 2013; Ellinger \& Ellinger, 2014). The highly importance of employee involvement as a factor in the successful implementation of supply chain integration, Huo, Han, Chen, \& Zhao (2015) show employee participation is positively associated with supply chain integration. Consequently, the relationship of employee involvement and supply chain integration as an organizational partner involved, is identified as a strong engagement. Based on the relationship between employee engagement and supply chain engagement it can be depicted a hypothesis as follows: H3: Employee Engagement positively affects Supply Chain Engagement

\section{Supply Chain Engagement and Business Performance}

The cooperation between industries in the supply chain is called supply chain engagement by Kagawa, Suh, Kondo, \& Nansai (2013) which are recognized as an important approach to collectively reduce costs, energy consumption, and clean environmental impacts. In an initial review study of Parkes et al. (2016) to Fishery Improvement Projects (FIPs) in which FIPs are multi stakeholder efforts to improve the sustainability performance of a fishery, usually through supply chain engagement. Using two existing databases for this analysis: the MSC's database of certification scores and EDF's global database of catch share fisheries. The results show that fisheries using catch share management had a higher probability of exceeding a threshold level for several Performance Indicators. In implementing the Supply Chain Engagement strategy and to understand the information from the environment, then it is necessary and important the manager's role to inform supply chain engagement and purchasing decisions (Pelton \& Smith, 2015). There are two different aspects of business performance: product-market performance and financial performance (Morgan, 2012). In the article would be developed product-market performance. According to Morgan (2012) Product-market performance concerns the purchase behavior responses of customers and prospects in the target market to the firm's realized positional advantage. Improved perceptions alter customers' buying behavior in a way that is favorable for the firm. All else being equal, this enhances product-market performance in ways that may be captured in indicators such as: greater sales volume, increased customer 
satisfaction and behavioral loyalty, lower price sensitivity, and growth in the firm's market share. Alternatively, a firm with a realized cost advantage to maintain existing perceptions and buying behavior patterns among target customers while enjoying a greater margin at the same selling price as competitors. Morgan, Clark, \& Gooner (2002) explain that market performance concerns market awareness and reactions to realized positional advantages achieved. These may be viewed from customer, competitor, and internal perspectives. From a customer perspective, market performance concerns cognitive and affective responses (e.g. brand awareness and perceived quality) and the subsequent behavioral consequences (e.g. purchase decision making and actions) of prospects and customers in the target market to the realized positional advantages achieved by the firm. From an internally oriented perspective, market performance is manifest in the subsequent effect of customer behaviors as seen in terms of unit sales and sales revenue. From a competitor perspective, market performance is seen in terms of indicators such as share of mind and market share. From a normative perspective, MPA therefore involves assessing marketing resources and capabilities as sources of advantage, positional advantages achieved, market performance from customer perceptions through customer behaviors to customer post-purchase outcomes (customer perspective) and unit sales, market share, etc. (firm perspective) to financial consequences (revenue, cash flow, and profits). The time taken between acquiring sources of advantage, achieving positional advantages, raising market performance, and the ultimate impact upon observed financial outcomes may vary significantly between industries. In a review of Moya \& Alemán (2012) on new product creativity, speed-to-market, new product performance, and moderating effects of marketplace characteristics on 197 manufacturing firms, it was found that knowledge reviewing plays an important role in enhancing new product performance, both directly and indirectly through new product creativity and speed-to-market that are contingent on the levels of market competition (Kotabe, Jiang, \& Murray, 2011). The changing of competitive maps is based on concerns about the sustainability of the natural environment as a business issue predicted by Leonidou, Katsikeas, \& Morgan (2013) due to the role of green marketing programs in influencing firm performance, the impact of slack resources and top management risk aversion on the deployment of such programs, and the conditioning effects that underpin these relationships. It was revealed that green marketing programs are being implemented by firms find evidence of significant performance payoffs. Specifically the results indicate that green product and distribution programs positively affect firms ' product- market performance, while green pricing and promotion practices are directly positively related to firms' return on assets. In addition, industry-level environmental reputation moderates the links between green 
marketing program components and firms' product-market and financial performance. Furthermore, Chen, Li, \& Liu (2015) investigated how multiple capabilities affecting the external environment (such as, the ability to influence government and to influence industry) can affect the market performance of new products in emerging markets and how organizational learning by explorative and exploitative firms in China; it was found that the ability to influence government positively affected the market performance of new products, while the ability to influence the industry have curvilinear (inverted U-shaped) effects on new product performance. And in both capabilities in influencing government and industry more favorably when matched by explorative learning, exploitative learning weakens both effects in influencing the market performance of new products. On examination of the product market spillover effects of hedge fund activism (HFA) on the industry rivals of target firms by Aslan \& Kumar (2016) has negative real and stockholder wealth effects on the average rival firm. The effects on rivals' product market performance are commensurate with post-activism improvements in target's productivity, cost and capital allocation efficiency, and product differentiation. These effects are observed on the product marker performance of rivals as measured by their price-cost markups and market shares, operational return, and capital investment. Thus post-investment management activism on productivity improvement targets is documented in recent reviews for major channels of spillover effects on their industry counterparts. Conversely, rivals respond to activism not only by reducing prices but by affecting the efficiency and improvement of product differences, the effect of the distribution of expansion of investment management activism commensurate with the improvement of distribution at rival firms. In addition, rivals' finances are limited by accommodating improvement targets but their peers are threatened by interventions to be able to improve product market performance following investment management activism within the firms' target. Industry concentration and entry threats also play an important role in determining the nature and magnitude of spillover effects. Based on the relationship between Supply Chain Engagement and Business Performance, it can be depicted a hypothesis as follows: H4: Supply Chain Engagement positively affects Business Performance

\section{RESEARCH METHODS}

\section{Data Collection}

A total of 393 of 22,889 MSME companies were selected randomly based on companies using offline and online marketing system in seven areas of Trade and Industry Center of Banyumas Regency- Indonesia. The firms are contacted by email and invited to participate in online 
surveys. Contact details of 143 firms were invalid leading to an effective sample frame of 250 . After 2 weeks of observation to the firms to ensure that the company has an offline and online sales outlet. Overall, 178 usable responses were obtained, resulting in an effective response rate of $71 \%$. The sample population includes owner, leader, and managers as firm informants on the strategic business unit level across different industries. Firm and informant descriptive statistics are shown in Table 2.

\section{Measures}

The measurement used is interval data with Agree-Disagree Scale technique in various value ranges (Ferdinand, 2014). The range used on scale 1 strongly disagrees until the 10th range strongly agrees (Blais \& Galais, 2016; Cook, Heath, Thompson, \& Thompson, 2001). This study uses five variables: market knowledge, customer engagement, employee engagement, supply chain engagement, and business performance. Dependent Variables. Business performance is an index of overall company capability as measured by operational indicators (Vij \& Bedi, 2016). Morgan (2012) explains in the process of research on dynamic marketing capabilities aimed at two different aspects of business performance i.e. product-market performance and financial performance. For the development of firm business performance indicators in this dissertation was adopted from Zacca, Dayan, \& Ahrens (2015) i.e. sales growth, market share growth, employee growth, profit growth, profit margin sales, and capital growth from sales profits. These performance indicators are related to the firms' growth, profitability, and capability. Independent Variables. The ability of market knowledge enables firms to perceive and take advantage of opportunities and identify threats from the real business market environment through scanning, searching and firm interpretation routines (D. J. Teece, 2009). Pérez-Cabañero, Cruz-Ros, \& González-Cruz (2015) argue that the ability of market knowledge is the ability to understand and develop skills to compile marketing intelligence in gathering data about competitors, customers, new market opportunities, and business trends. Based on the opinion of Pérez-Cabañero, Cruz-Ros, \& González-Cruz (2015) that an indicator of market knowledge, such as; the ability to identify customers and actual markets, ability to identify competitors, ability to identify new business trends, and ability to identify the accuracy of profitability and revenue forecasting. The literature analysis by Islam \& Rahman (2016c) explains that customer engagement is described as an approach to create, build and improve customer relationships and is considered a very important strategy for building sustainable competitive advantage (Doorn van et al., 2010; Brodie et al. (2013) .The conceptualization they identified in the marketing discipline revealed that some studies of customer engagement such 
as Doorn van et al. (2010) say that it is unidimensional. Consequently, firms focus on customers of different factors to achieve competitive advantage. This conceptualization explains that theories of customer engagement discuss the experience of interactive services and marketing relationships between different stakeholders in value creation, while Banyte, Tarute, \& Taujanskyte (2014) confirm a strong relationship between customer engagement in value creation. In Jahn \& Kunz (2012) scale measurement used for customer engagement, developed based on the conceptualization of the construction of Doorn van et al. (2010) that give rise to indicators such as integration, bound, active, participation, and interaction. The indicator is also a reference of Vries \& Carlson (2014) in his research to measure the construct of functional value, hedonic value, the value of social interaction, intensity of use and customer engagement. Based on the explanation of the literature, the construct of customer insight in this dissertation research, adopted the indicator developed by Jahn \& Kunz (2012) from Doorn van et al. (2010) to build a sustainable competitive advantage (Islam \& Rahman, 2016c). Kumar \& Pansari (2015) define employee engagement as a multidimensional consisting of all the different aspects of employee attitudes and behaviors towards the organization (Kumar \& Pansari (2014), while Thomas (2007) defines employee engagement as follows: employee engagement is a psychological state which is relatively stable influenced by the interaction of the individual and their working environment. Interested employees are characterized by readiness and willingness to direct personal energy into the physical, cognitive, and emotional expression associated with fulfilling a necessary and discretionary work role, which becomes the basis of adoption as an indicator on employee engagement, such as: sincerity, dedication, effectiveness, enthusiasm, extra work, performance, pride, determination, heart and soul. Moderating Variable. Supply chain engagement is a market-segmented value chain collaboration agreement to help achieve business goals. Cai, Huang, Liu, \& Liang (2016) define supply chain collaboration with "a process of partnership between two or more interconnected firms working accurately to plan and implement supply chain operations toward mutual and mutually beneficial goals". Based on this, the supply chain indicator is adopted from Cai, Huang, Liu, \& Liang (2016), such as; making decisions together, designing products together, contributing to the improvement and sharing of information.

\section{Construct Validation}

Validity and reliability tests are performed to ensure that the indicators and variables in the study are valid and reliable for further analysis presented in tables 3. Further, hypothesis testing 
is done using full model structure. This test uses the AMOS program as a confirmatory factor analysis for exogenous and endogenous constructs.

\section{Data Analysis Approach}

\section{Sample Sufficiency Assumption.}

according to Jr. et al., (2013) for $\mathrm{n}<250$ with an indicator $<30$ requires a significant level with TLI and CFI of 0.95 as a condition of the fit model. From the results of the full structural model analysis above, the criteria have been qualified. The empirical research model developed refers to the confirmatory factor analysis of endogenous constructs, presented in Table 4.

\section{RESULT}

\section{Structural Equation Modeling Result}

In table 5 and figure 2, we present two models estimated using both the perceptual and the objective measures to test our hypotheses. All hypothesized relationships show similar results in terms of directionality and significance between the two estimation approaches. H1a,b, is

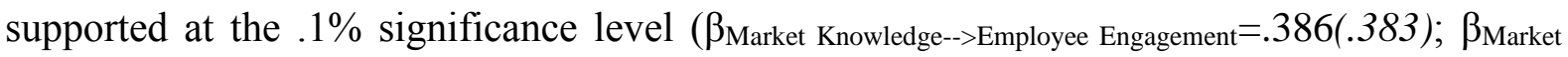
Knowledge-->Employee Engagement $=.479(.487))$; Different from H1c is supported at the $.5 \%$ significance

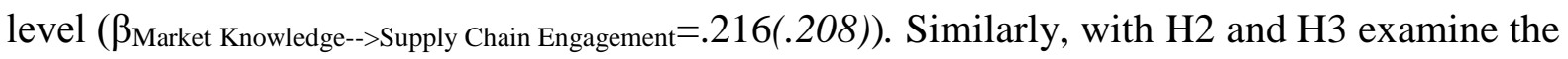
engagement of Customer Engagement and Employee Engagement to Supply Chain

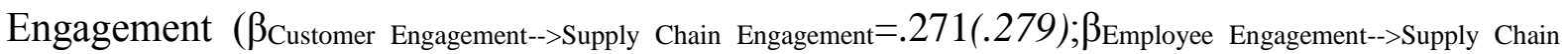
Engagement $=.393(.383))$. Furthermore, Supply Chain Engagement positively influences the Business Performance, but not with the second model ( $\beta_{\text {Supply }}$ Chain Engagement-->Business Performance $=.313(.174)$; while the direct relationship of Customer Engagement and Employee Engagement to Business Performance not tested in the first model shows that the direct relationship of Customer Engagement to Business Performance is not positive ( $\beta_{\text {Customer }}$ Engagement- $>$ Business Performance $=(-.090)$; while Employee Engagement positively affects on Business Performance with a significant level of .01 ( $\left.\beta_{\text {Employee Engagement-- }>\text { Business Performance }}=.300\right)$. We then tested the Supply Chain Engagement variable as the mediator variable using the second model data using the test sobel at http://www.danielsoper.com, The results indicate that the Supply Chain Supplier variable is not able to mediate between Customer Engagement variables with Business Performance, where the value of $Z=-0.95176074<1.98$ and the value of P-val 0.34121834 below the significance of 0.05. But unlike the Employee Engagement variable, Supply Chain Engagement variable is able to mediate to Business Performance where 
the value of $\mathrm{Z}=-2.53266221>1.98$ and the value of $\mathrm{P}$-val 0.011320 under the significance of 0.05 .

\section{DISCUSSION}

\section{Contribution to the Supply Chain Literature}

The supply chain engagement viewed by Kagawa, Suh, Kondo, \& Nansai (2013) and Parkes et al. (2016) has been recognized as an important approach in the industry, while we consider it extremely important in marketing that can improve business performance (Yunus \& Tadisina, 2016; Vanichchinchai,2012). We also agree with several studies, agreeing to involve the supply chain in an engagement of management superintendence (Harland,1996; Croxton, GarcíaDastugue, Lambert, \& Rogers, 2001; Skjoett-Larsen, Thernoe, \& Andresen, 2003). While our results show that customer engagement directly and indirectly has no effect on business performance, it is different from the increasingly competitive global market needs, as well as the findings (Kannan \& Choon Tan, 2006; Danese \& Romano, 2011; Yu, Jacobs, Salisbury, \& Enns, 2013; Y. He, Keung Lai, Sun, \& Chen, 2014; Siew-Phaik, Downe, \& Sambasivan, 2013). Although different but we agree that involving the customer to integrate with the supply chain in an engagement is positive. While in the creation of knowledge of competitive markets, supply chain engagement becomes an efficient, operational and interrelated process of information to organizations. As in Feng \& Wang (2013) research, supply engagement is related to customer and supplier engagement positively, but it can improve performance (Kanapathy, Khong, \& Dekkers, 2014; Feng \& Zhao, 2014). We hope this discussion can be a future reference to further research in the supply chain's engagement to business performance especially in small and medium-sized firms that have implemented business in two marketing systems (offline and online).

\section{Implications for SME's Corporate Practice}

The ability of connecting providers and other customers interacted in a sustainable value creation process. This concerns the physical link that connects customers and raw material suppliers as part of channel members. It is expected that $M S M E$ can integrate a supply chain that has activities with firms in making decision together, engaging in designing shared products can share cross-functional processes to improve and share information with the firm. This can be acted upon because the Supply Chain has activities with the company in joint decision making for the benefit of the company and contributes to the marketing strategy, talks about the most popular prices and goods, designs and gives choices in design with customers 
and provides examples of new product models and joint options design with customers towards the firm. Cross-functionally in the process of improvement, the supply chain has alerted the company if anyone made a mistake and shared information about what employees are doing about their respective performance and gives advice on what the company should do. In addition, the supply chain also provides information on market conditions, prices and the latest products of competitors.

\section{CONCLUSION, LIMITATIONS, AND FUTURE RESEARCH}

The findings are able to contribute positively to the development of marketing and operational strategy theory in establishing relationships with customers and employees through market knowledge in an engagement mediated by supply chain engagement to improve the business performance of MSME. Supply chain engagement proved able to contribute activities in marketing function to business operation in an engagement. Supply chain engagement provides managerial contribution for MSME managers as policy decision making in executing business strategy of offline and online. The limitations of this study are related to the process and the results of research. The relationship between the variables built in the empirical model still yields a marginal relationship that needs to reexamine the indicators that affect the significance and the congeniality of model. Although this study is in line with Wilhelm, Schlömer, \& Maurer (2015) who found dynamic ability in a high dynamic environment led to higher efficiency of routine operations and Alfalla-Luque, Marin-Garcia, \& Medina-Lopez (2015) who found the relationship between employee commitment and operational performance is fully mediated by supply chain integration. Future research is expected to follow up this study by differentiating the research sample as well as improving with the wider area to get the comparison. Although necessary for follow-up, the most important thing is to find more specific measures and measurements, perhaps with different times and places for supply chain engagement.

\section{REFERENCES}

Alfalla-Luque, R., Marin-Garcia, J. A., \& Medina-Lopez, C. (2015). An analysis of the direct and mediated effects of employee commitment and supply chain integration on organisational performance. International Journal of Production Economics, 162, 242257. https://doi.org/10.1016/j.ijpe.2014.07.004

Andrew, O. C., \& Sofian, S. (2012). Individual Factors and Work Outcomes of Employee Engagement. Procedia - Social and Behavioral Sciences, 40, 498-508. https://doi.org/10.1016/j.sbspro.2012.03.222 
Aslan, H., \& Kumar, P. (2016). The product market effects of hedge fund activism. Journal of Financial Economics, 119(1), 226-248. https://doi.org/10.1016/j.jfineco.2015.08.016

Attaran, M., \& Attaran, S. (2007). Collaborative supply chain management: The most promising practice for building efficient and sustainable supply chains. Business Process Management Journal, 13(3), 390-404. https://doi.org/10.1108/14637150710752308

Augier, M., \& Teece, D. J. (2007). Dynamic Capabilities and Multinational Enterprise : Penrosean Insights and Omissions. Management International Review, 47(2), 175-192. https://doi.org/10.1007/s11575-007-0010-8

Banyte, J., Tarute, A., \& Taujanskyte, I. (2014). Customer Engagement into Value Creation: Determining Factors and Relations with Loyalty. Engineering Economics, 25(5), 568577. https://doi.org/10.5755/j01.ee.25.5.8402

Bao, Y., Sheng, S., \& Zhou, K. Z. (2012). Network-based market knowledge and product innovativeness. Marketing Letters, 23(1), 309-324. https://doi.org/10.1007/s11002-0119155-0

Barrales-Molina, V., Martínez-López, F. J., \& Gázquez-Abad, J. C. (2014). Dynamic marketing capabilities: Toward an integrative framework. International Journal of Management Reviews, 16(4), 397-416. https://doi.org/10.1111/ijmr.12026

Barth, J. E. (Joe). (2007). Customer engagement and the operational efficiency of wine retail stores. International Journal of Wine Business Research, 19(3), 207-215. https://doi.org/10.1108/17511060710817230

Berning, A., \& Venter, C. (2015). Sustainable Supply Chain Engagement in a Retail Environment. Sustainability, 7(5), 6246-6263. https://doi.org/10.3390/su7056246

Beske, P. (2012). Dynamic capabilities and sustainable supply chain management. International Journal of Physical Distribution \& Logistics Management, 42(4), 372387. https://doi.org/10.1108/09600031211231344

Blais, A., \& Galais, C. (2016). Measuring the civic duty to vote : A proposal. Electoral Studies, 41, 60-69. https://doi.org/10.1016/j.electstud.2015.11.003

Bogdanowicz, M. S. (2002). The value of knowledge and the values of the new knowledge worker: generation X in the new economy. Journal of European Industrial Training, 26, 125-129. https://doi.org/10.1108/03090590210422003

Brodie, R. J., Ilic, A., Juric, B., \& Hollebeek, L. (2013). Consumer engagement in a virtual brand community: An exploratory analysis. Journal of Business Research, 66(1), 105114. https://doi.org/10.1016/j.jbusres.2011.07.029

Cai, Z., Huang, Q., Liu, H., \& Liang, L. (2016). The moderating role of information technology capability in the relationship between supply chain collaboration and organizational responsiveness: evidence from China. International Journal of Operations \& Production Management, 36(10). https://doi.org/10.1108/IJOPM-082014-0406

Cambra-Fierro, J. J., Melero-Polo, I., \& Vázquez-Carrasco, R. (2013). Customer engagement: Innovation in non-technical marketing processes. Innovation: Management, Policy \& Practice, 15(3), 326-336. https://doi.org/10.5172/impp.2013.15.3.326

Cambra-Fierro, J., Melero-Polo, I., \& Javier Sese, F. (2015). Can complaint-handling efforts promote customer engagement? Service Business. https://doi.org/10.1007/s11628-0150295-9 
Carter, T. (2008). Customer Engagement and Behavioral Considerations. Journal of Strategic Marketing, 16(1), 21-26. https://doi.org/10.1080/09652540701794387

Chen, H., Li, Y., \& Liu, Y. (2015). Dual capabilities and organizational learning in new product market performance. Industrial Marketing Management, 46, 204-213. https://doi.org/10.1016/j.indmarman.2015.02.031

Chen, K.-H., Wang, C.-H., Huang, S.-Z., \& Shen, G. C. (2016). Service innovation and new product performance: The influence of market-linking capabilities and market turbulence. International Journal of Production Economics, 172, 54-64. https://doi.org/10.1016/j.ijpe.2015.11.004

Chen, Y., Tang, G., Jin, J., Li, J., \& Paille, P. (2015). Linking Market Orientation and Environmental Performance: The Influence of Environmental Strategy, Employee's Environmental Involvement, and Environmental Product Quality. Journal of Business Ethics, 1-22. https://doi.org/10.1007/s10551-014-2059-1

Chow, W. S., Madu, C. N., Kuei, C.-H., Lu, M. H., Lin, C., \& Tseng, H. (2008). Supply chain management in the US and Taiwan: An empirical study. Omega, 36(5), 665-679. https://doi.org/10.1016/j.omega.2006.01.001

Cook, C., Heath, F., Thompson, R. L., \& Thompson, B. (2001). Score reliability in Webor internet-based surveys: unnumbered graphic rating scales versus likert-type scales. Educational and Psychological Measurement, 61(4), 697-706. https://doi.org/10.1177/00131640121971356

Croxton, K. L., García-Dastugue, S. J., Lambert, D. M., \& Rogers, D. S. (2001). The Supply Chain Management Processes. International Journal of Logistics Management, 12(2), 13-36.

Cui, A. S., \& Wu, F. (2015). Utilizing customer knowledge in innovation: antecedents and impact of customer involvement on new product performance. Journal of the Academy of Marketing Science. https://doi.org/10.1007/s11747-015-0433-X

Danese, P., \& Romano, P. (2011). Supply chain integration and efficiency performance: a study on the interactions between customer and supplier integration. Supply Chain Management: An International Journal, 16(4), 220-230. https://doi.org/10.1108/13598541111139044

Darkow, I. L. (2014). The involvement of middle management in strategy development Development and implementation of a foresight-based approach. Technological Forecasting and Social Change, 101, 10-24. https://doi.org/10.1016/j.techfore.2013.12.002

Devi, V. R. (2009). Employee engagement is a two-way street. Human Resource Management International Digest, 17(2), 3-4. https://doi.org/10.1108/09670730910940186

Doorn van, J., Lemon, K. N., Mittal, V., Nass, S., Pick, D., Pirner, P., \& Verhoef, P. C. (2010). Customer Engagement Behavior: Theoretical Foundations and Research Directions. Journal of Service Research, 13(3), 253-266. https://doi.org/10.1177/1094670510375599

Duffy, R., Fearne, A., Hornibrook, S., Hutchinson, K., \& Reid, A. (2013). Engaging suppliers in CRM: The role of justice in buyer-supplier relationships. International Journal of Information Management, 33(1), 20-27. https://doi.org/10.1016/j.ijinfomgt.2012.04.005 
Ellinger, A. E., \& Ellinger, A. D. (2014). Leveraging human resource development expertise to improve supply chain managers' skills and competencies. European Journal of Training and Development, 38(1/2), 118-135. https://doi.org/10.1108/EJTD-09-20130093

Fang, E. (Er), \& Zou, S. (2009). Antecedents and consequences of marketing dynamic capabilities in international joint ventures. Journal of International Business Studies, 40(5), 742-761. https://doi.org/10.1057/jibs.2008.96

Feng, T., \& Wang, D. (2013). Supply chain involvement for better product development performance. Industrial Management \& Data Systems, 113(2), 190-206. https://doi.org/10.1108/02635571311303532

Feng, T., \& Zhao, G. (2014). Top management support, inter-organizational relationships and external involvement. Industrial Management \& Data Systems, 114(4), 526-549. https://doi.org/10.1108/IMDS-03-2013-0127

Ferdinand, A. (2014). Metode Penelitian Manajemen: Pedoman Penelitian untuk Penulisan Skripsi, Tesis, dan Disertasi Ilmu Manajemen (Kelima). Semarang: Badan Penerbit Universitas Diponegoro.

Harland, C. M. (1996). Supply Chain Management: Relationships, Chains and Networks. British Journal of Management, 7, 63-80. https://doi.org/10.1111/j.14678551.1996.tb00148.x

He, Y., Keung Lai, K., Sun, H., \& Chen, Y. (2014). The impact of supplier integration on customer integration and new product performance: The mediating role of manufacturing flexibility under trust theory. International Journal of Production Economics, 147, 260-270. https://doi.org/10.1016/j.ijpe.2013.04.044

Helfat, C. E., \& Peteraf, M. A. (2003). The dynamic resource-based view: Capability lifecycles. Strategic Management Journal, 24(10), 997-1010. https://doi.org/10.1002/smj.332

Hong C. Zhang, Kuo, T. C., Lu, H., \& Huang, S. H. (1997). Environmentally Conscious Design and Manufacturing: A State-of-the-Art Survey. Journal of Manufacturing Systems, 16(5), 352-371. https://doi.org/10.1016/S0278-6125(97)88465-8

Huo, B., Han, Z., Chen, H., \& Zhao, X. (2015). The effect of high-involvement human resource management practices on supply chain integration. International Journal of Physical Distribution \& Logistics Management, 45(8), 716-746. https://doi.org/10.1108/IJPDLM-05-2014-0112

III, C. R. G., \& Tallon, W. J. (2003). Enhancing supply chain practices through human resource management. Journal of Management Development, 22(1), 32-44. https://doi.org/10.1108/02621710310454842

Islam, J. U., \& Rahman, Z. (2016). The Transpiring Journey of Customer Engagement Research in Marketing: A Systematic Review of the Past Decade. Management Decision, 54(8). https://doi.org/10.1108/MD-01-2016-0028

Jahn, B., \& Kunz, W. (2012). How to transform consumers into fans of your brand. Journal of Service Management, 23(3), 344-361. https://doi.org/10.1108/09564231211248444

Jr., J. F. . H., Black, W. C. ., Babin, B. J., \& Anderson, R. E. (2013). Multivariate Data Analysis (Seventh). Pearson Education Limited.

Kagawa, S., Suh, S., Kondo, Y., \& Nansai, K. (2013). Identifying environmentally important 
supply chain clusters in the automobile industry. Economic Systems Research, 25(3), 265-286. https://doi.org/10.1080/09535314.2012.730992

Kahn, W. a. (1990). Psychological Conditions of Personal Engagement and Disengagement At Work. The Academy of Management Journal, 33(4), 692-724. https://doi.org/10.2307/256287

Kanapathy, K., Khong, K. W., \& Dekkers, R. (2014). New product development in an emerging economy: Analysing the role of supplier involvement practices by using Bayesian Markov Chain Monte Carlo technique. Journal of Applied Mathematics, 2014, 1-12. https://doi.org/10.1155/2014/542606

Kannabiran, G. (2009). Sustainable stakeholder engagement through innovative supply chain strategy: An exploratory study of an Indian organization. Asian Business \&\#38; Management, 8(2), 205-223. https://doi.org/10.1057/abm.2009.6

Kannan, V. R., \& Choon Tan, K. (2006). Buyer-supplier relationships: The impact of supplier selection and buyer-supplier engagement on relationship and firm performance.

International Journal of Physical Distribution \& Logistics Management, 36(10), 755775. https://doi.org/10.1108/09600030610714580

Klevas, J. (2005). Organization of packaging resources at a product-developing company. International Journal of Physical Distribution \& Logistics Management, 35(2), 116131. https://doi.org/10.1108/09600030510590309

Kotabe, M., Jiang, C. X., \& Murray, J. Y. (2011). Managerial ties, knowledge acquisition, realized absorptive capacity and new product market performance of emerging multinational companies: A case of China. Journal of World Business, 46(2), 166-176. https://doi.org/10.1016/j.jwb.2010.05.005

Kumar, V., Aksoy, L., Donkers, B., Venkatesan, R., Wiesel, T., \& Tillmanns, S. (2010). Undervalued or Overvalued Customers: Capturing Total Customer Engagement Value. Journal of Service Research, 13(3), 297-310. https://doi.org/10.1177/1094670510375602

Kumar, V., \& Pansari, A. (2014). The Construct, Measurement, and Impact of Employee Engagement: a Marketing Perspective. Customer Needs and Solutions, 1(1), 52-67. https://doi.org/http://dx.doi.org/10.1007/s40547-013-0006-4

Lamothe, J., Hadj-hamou, K., \& Aldanondo, M. (2006). An optimization model for selecting a product family and designing its supply chain. European Journal of Operational Research, 169(3), 1030-1047. https://doi.org/10.1016/j.ejor.2005.02.007

Lavie, D. (2006). Capability Reconfiguration: An Analysis of Incumbent Responses to Technological Change. The Academy of Management Review, 31(1), 153-174. https://doi.org/10.5465/AMR.2006.19379629

Leonidou, C. N., Katsikeas, C. S., \& Morgan, N. A. (2013). "Greening” the marketing mix: Do firms do it and does it pay off? Journal of the Academy of Marketing Science, 41(2), 151-170. https://doi.org/10.1007/s11747-012-0317-2

Macey, W. H., \& Schneider, B. (2008). The Meaning of Employee Engagement. Industrial and Organizational Psychology, 1, 3-30. https://doi.org/10.1111/j.17549434.2007.0002.x

Malhotra, A., Gosain, S., \& Sawy, O. A. El. (2005). Absorptive Capacity Configurations in Supply Chains: Gearing for Partner-Enabled Market Knowledge Creation. MIS 
Quarterly, 29(1), 145-187. Retrieved from http://www.jstor.org/stable/25148671

Mazdeh, M. M., Akhaven, P., Jafari, M., \& Mousavi, S. J. (2014). A supply chain framework for knowledge creation in new product development. Applied Mathematics in Engineering, Management and Technology, 626-640. Retrieved from $\mathrm{http}: / /$ ssrn.com/abstract=2503305

Morgan, N. A. (2012). Marketing and business performance. Journal of the Academy of Marketing Science, 40(1), 102-119. https://doi.org/10.1007/s11747-011-0279-9

Morgan, N. A., Clark, B. H., \& Gooner, R. (2002). Marketing productivity, marketing audits, and systems for marketing performance assessment: Integrating multiple perspectives. Journal of Business Research, 55(5), 363-375. https://doi.org/10.1016/S01482963(00)00162-4

Moya, M. M., \& Alemán, J. L. M. (2012). La Revisión Del Conocimiento En Los Nuevos Productos: El Papel Mediador De La Creatividad Y La Velocidad Al Mercado. Revista Española de Investigación En Marketing ESIC, 16(1), 59-85. https://doi.org/10.1016/S1138-1442(14)60009-7

Mulvey, P. W., LeBlanc, P. V, Heneman, R. L., \& McInerney, M. (2002). Study finds that knowledge of pay process can beat out amount of pay in employee retention, organizational effectiveness. Journal of Organizational Excellence, 21(4), 29-42. https://doi.org/10.1002/npr.10041

Parkes, G., Swasey, J. H., Underwood, F. M., Fitzgerald, T. P., Strauss, K., \& Agnew, D. J. (2016). The effects of catch share management on MSC certification scores. Fisheries Research, 182, 18-27. https://doi.org/10.1016/j.fishres.2015.10.003

Pelton, R. E. O., \& Smith, T. M. (2015). Hotspot Scenario Analysis. Journal of Industrial Ecology, 19(3), 427-440. https://doi.org/10.1111/jiec.12191

Pérez-Cabañero, C., Cruz-Ros, S., \& González-Cruz, T. (2015). The contribution of dynamic marketing capabilities to service innovation and performance. International Journal of Business Environment, 7(1), 61-77. https://doi.org/10.1504/ijbe.2015.065996

Petersen, K. J., Handfield, R. B., \& Ragatz, G. L. (2005). Supplier integration into new product development: Coordinating product, process and supply chain design. Journal of Operations Management, 23(3-4), 371-388. https://doi.org/10.1016/j.jom.2004.07.009

Primo, M. a M., \& Amundson, S. D. (2002). An exploratory study of the effects of supplier relationships on new product development outcomes. Journal of Operations Management, 20(1), 33-52. https://doi.org/10.1016/S0272-6963(01)00080-8

Ragatz, G. L., Handfield, R. B., \& Scannell, T. V. (1997). Success Factors for Integrating Suppliers into New Product Development. Journal of Product Innovation Management, 14(3), 1990-202. https://doi.org/10.1111/1540-5885.1430190

Rantavaara, A., Wallin, H., Hasunen, K., Härmälä, K., Kulmala, H., Latvio, E., ... Tainio, R. (2005). Finnish stakeholder engagement in the restoration of a radioactively contaminated food supply chain. Journal of Environmental Radioactivity, 83(3 SPEC. ISS.), 305-317. https://doi.org/10.1016/j.jenvrad.2004.04.013

Romanou, N., Soane, E., Truss, K., Alfes, K., Rees, C., Gatenby, M., ... Karamberi, M. (2010). Managerial perspectives on employee engagement. Annals of General Psychiatry, 9((Suppl 1)), S172. https://doi.org/10.1186/1744-859X-9-S1-S172

Rothmann, S., \& Rothmann Jr, S. (2010). Factors associated with employee engagement in 
South Africa. SA Journal of Industrial Psychology, 36(2), 1-12.

https://doi.org/10.4102/sajip.v36i2.925

Sahay, B. S. (2003). Supply chain collaboration: the key to value creation. Work Study, 52(2), 76-83. https://doi.org/10.1108/00438020310462872

Saunders, L. W., Kleiner, B. M., McCoy, A. P., Lingard, H., Mills, T., Blismas, N., \& Wakefield, R. (2015). The effect of early supplier engagement on social sustainability outcomes in project-based supply chains. Journal of Purchasing and Supply Management, 21, 1-11. https://doi.org/10.1016/j.pursup.2015.05.004

Shub, A. N., \& Stonebraker, P. W. (2009). The human impact on supply chains: evaluating the importance of "soft" areas on integration and performance. Supply Chain Management, 14(1), 31-40. https://doi.org/http://dx.doi.org/10.1108/13598540910927287

Shuck, B., Reio, T. G., \& Rocco, T. S. (2011). Employee engagement: an examination of antecedent and outcome variables. Human Resource Development International, 14(4), 427-445. https://doi.org/10.1080/13678868.2011.601587

Shuck, M. B., Rocco, T. S., \& Albornoz, C. a. (2011). Exploring employee engagement from the employee perspective: implications for HRD. Journal of European Industrial Training, 35(4), 300-325. https://doi.org/10.1108/03090591111128306

Siew-Phaik, L., Downe, A. G., \& Sambasivan, M. (2013). Strategic alliances with suppliers and customers in a manufacturing supply chain. Asia - Pacific Journal of Business Administration, 5(3), 192-214. https://doi.org/10.1108/APJBA-11-2012-0077

Simard, A. (2006). Knowledge markets: more than providers and users. In The IPSI BgD Transactions on Advanced Research (pp. 3-9). New York, Frankfurt, Tokyo, Belgrade: IPSI Bgd Internet Research Society. Retrieved from www.internetjournals.net

Singh, P. J., \& Power, D. (2009). The nature and effectiveness of collaboration between firms, their customers and suppliers: a supply chain perspective. Supply Chain Management: An International Journal, 14(3), 189-200. https://doi.org/10.1108/13598540910954539

Skjoett-Larsen, T., Thernoe, C., \& Andresen, C. (2003). Supply chain collaboration: Theoretical perspectives and empirical evidence. International Journal of Physical Distribution \& Logistics Management, 33(6), 531-549. https://doi.org/10.1108/09600030310492788

Stander, M. W., \& Rothmann, S. (2010). Psychological empowerment, job insecurity and employee engagement. SA Journal of Industrial Psychology, 36(1), 1-8. https://doi.org/10.4102/sajip.v36i1.849

Storbacka, K., Brodie, R. J., Böhmann, T., Maglio, P. P., \& Nenonen, S. (2016). Actor engagement as a microfoundation for value co-creation. Journal of Business Research, 69(8), 3008-3017. https://doi.org/10.1016/j.jbusres.2016.02.034

Sumitro. (2016). Analisis Kualitas Produk, Harga, Kepuasan Konsumen Pada Minat Membeli Ulang: Studi Kasus Pada Industri Kecil Di Labuhanbatu. Jurnal Kewirausahaan Dan Usaha Kecil Menengah, 1(1), 37-40.

Sundaray, B. K. (2011). Employee Engagement : A Driver of Organizational Effectiveness. European Journal of Business and Management, 3(8), 53-60.

Sweeney, E. (2013). The people dimension in logistics and supply chain management-its role 
and importance. In R. Passaro \& A. Thomas (Eds.), Supply Chain Management: Perspectives, Issues and Cases (Eds, pp. 73-82). Milan: McGraw-Hill.

Tan, Q., \& Sousa, C. M. P. (2015). Leveraging Marketing Capabilities into Competitive Advantage and Export Performance. International Marketing Review, 32(1), 78-102. https://doi.org/10.1063/1.2756072

Tapscott, D., Ticoll, D., \& Lowy, A. (2000). Digital Capital: Harnessing the Power of Business Webs. Harvard Business School Press. https://doi.org/10.1017/CBO9781107415324.004

Tapscott, D., \& Williams, A. D. (2008). Wikinomics : how mass collaboration changes everything (Expanded). The Penguin Group.

Teece, D. J. (2009). Dynamic Capabilities and Strategic Management: Organizing for Innovation and Growth. Oxford University Press, USA.

Teece, D. J., Pisano, G., \& Shuen, A. (1997). Dynamic Capabilities and Strategic Management. Strategic Management Journal, 18(7), 509-533.

Thomas, C. H. (2007). A New Measurement Scale For Employee Engagement: Scale Development, Pilot Test, And Replication. In Academy of Management Proceedings (pp. 1-6). https://doi.org/10.5465/AMBPP.2007.26501848

Thron, T., Nagy, G., \& Wassan, N. (2006). The impact of various levels of collaborative engagement on global and individual supply chain performance. International Journal of Physical Distribution \& Logistics Management, 36(8), 596-620. https://doi.org/10.1108/09600030610702880

Umar, I. A., \& Chawaguta, B. (2014). Strengthening Human Resources for Supply Chain Management in the immunization supply chain in Nigeria through stakeholder engagement. Journal of Pharmaceutical Policy and Practice, 7(Suppl 1), 8. https://doi.org/10.1186/2052-3211-7-S1-O8

Van Schalkwyk, S., Du Toit, D. H., Bothma, A. S., \& Rothmann, S. (2010). Job insecurity, leadership empowerment behaviour, employee engagement and intention to leave in a petrochemical laboratory. SA Journal of Human Resource Management, 8(1), 1-8. https://doi.org/10.4102/sajhrm.v8i1.234

Vanichchinchai, A., \& Igel, B. (2011). The impact of total quality management on supply chain management and firm's supply performance. International Journal of Production Research, 49(11), 3405-3424. https://doi.org/10.1080/00207543.2010.492805

Verhoef, P. C., Reinartz, W. J., \& Krafft, M. (2010). Customer Engagement as a New Perspective in Customer Management. Journal of Service Research, 13(3), 247-252. https://doi.org/10.1177/1094670510375461

Vij, S., \& Bedi, H. S. (2016). Are subjective business performance measures justified? International Journal of Productivity and Performance Management, 65(5). https://doi.org/10.1108/IJPPM-12-2014-0196

Vivek, S. D., Beatty, S. E., Dalela, V., \& Morgan, R. M. (2014). A Generalized Multidimensional Scale for Measuring Customer Engagement. Journal of Marketing Theory and Practice, 22(4), 401-420. https://doi.org/10.2753/MTP1069-6679220404

Vries, N. J. De, \& Carlson, J. (2014). Examining the drivers and brand performance implications of customer engagement with brands in the social media environment. Journal of Brand Management, 21(6), 495-515. https://doi.org/10.1057/bm.2014.18 
Walton, S. V, \& Handfield, R. B. (1998). The Green Supply Chain: Integrating Suppliers into Environmental Management Processes. International Journal of Purchasing \& Materials Management, 34(2), 2-11. https://doi.org/10.1111/j.1745493X.1998.tb00042.x

Wilhelm, H., Schlömer, M., \& Maurer, I. (2015). How dynamic capabilities affect the effectiveness and efficiency of operating routines under high and low levels of environmental dynamism. British Journal of Management, 26(2), 327-345. https://doi.org/10.1111/1467-8551.12085

Xu, J., \& Thomas, H. C. (2011). How can leaders achieve high employee engagement? Leadership \& Organization Development Journal, 32(4), 399-416. https://doi.org/10.1108/01437731111134661

Yu, W., Jacobs, M. A., Salisbury, W. D., \& Enns, H. (2013). The effects of supply chain integration on customer satisfaction and financial performance: An organizational learning perspective. International Journal of Production Economics, 146(1), 346-358. https://doi.org/10.1016/j.ijpe.2013.07.023

Yunus, E. N., \& Tadisina, S. K. (2016). Drivers of supply chain integration and the role of organizational culture. Business Process Management Journal, 22`(1), 89-115. https://doi.org/10.1108/BPMJ-12-2014-0127

Zacca, R., Dayan, M., \& Ahrens, T. (2015). Impact of network capability on small business performance Introduction. Management Decision, 53(1), 2-23. https://doi.org/10.1108/MD-11-2013-0587 
FIGURE 1

Model Involvement of Supply Chain in Engagement

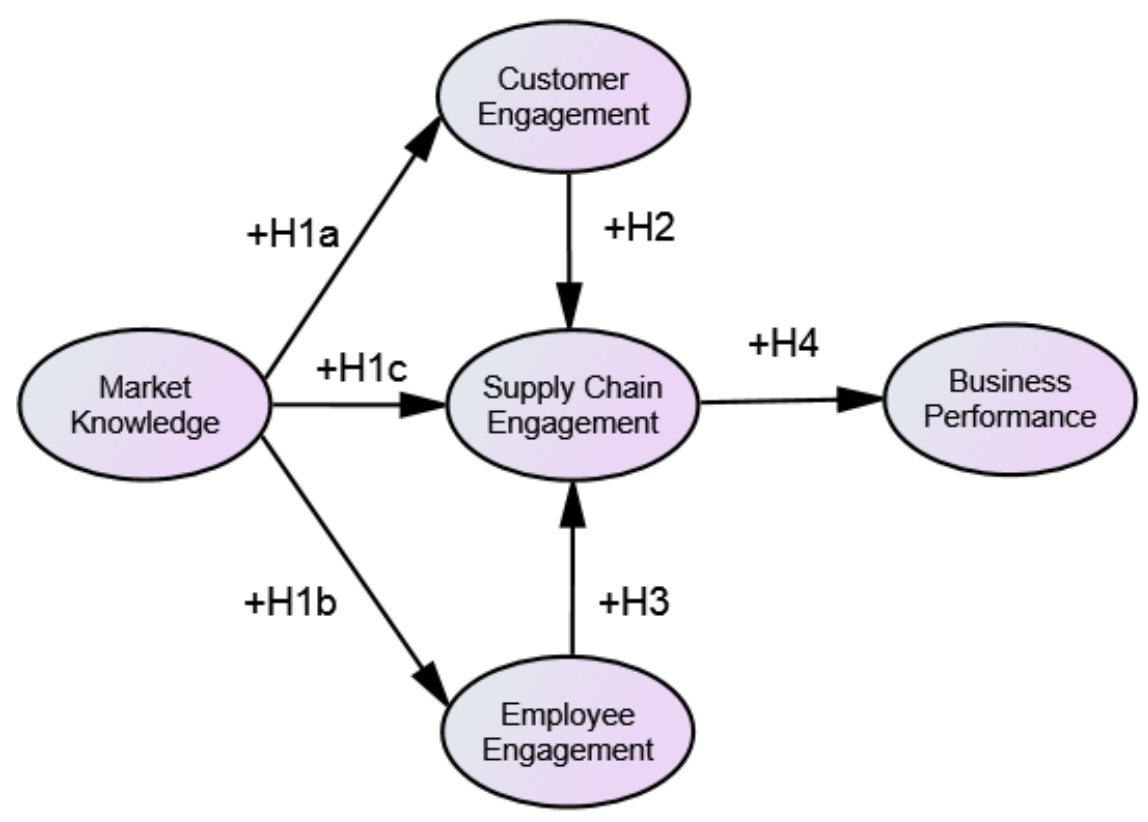


TABLE 1

Construct Description

\begin{tabular}{|c|c|c|}
\hline $\begin{array}{l}\text { Construct } \\
\text { Name }\end{array}$ & Description & Based On \\
\hline $\begin{array}{l}\text { Market } \\
\text { Knowledge }\end{array}$ & $\begin{array}{l}\text { The ability of market knowledge is the ability to understand } \\
\text { and develop skills to compile marketing intelligence in } \\
\text { gathering data about competitors, customers, new market } \\
\text { opportunities and business trends }\end{array}$ & $\begin{array}{c}\text { Pérez- } \\
\text { Cabañero, } \\
\text { Cruz-Ros, \& } \\
\text { González-Cruz } \\
\text { (2015) }\end{array}$ \\
\hline $\begin{array}{l}\text { Employee } \\
\text { Engagement }\end{array}$ & $\begin{array}{l}\text { Manifestation of customer behavior towards a brand or } \\
\text { company, beyond purchase, resulting from a motivational } \\
\text { rudder. }\end{array}$ & $\begin{array}{l}\text { Doorn van et } \\
\text { al. (2010); } \\
\text { Jahn \& Kunz } \\
\quad(2012)\end{array}$ \\
\hline $\begin{array}{l}\text { Customer } \\
\text { Engagement }\end{array}$ & $\begin{array}{l}\text { Employee engagement is a relatively stable psychological } \\
\text { state affected by the interaction of the individual and their } \\
\text { work environment. The employees involved are characterized } \\
\text { by readiness and willingness to direct personal energy into the } \\
\text { physical, cognitive, and emotional expression associated with } \\
\text { fulfilling the necessary work role and discretionary }\end{array}$ & Thomas (2007) \\
\hline $\begin{array}{l}\text { Supply } \\
\text { Chain } \\
\text { Engagement }\end{array}$ & $\begin{array}{l}\text { The process of partnership between two or more } \\
\text { interconnected companies works closely to plan and } \\
\text { implement supply chain operations toward mutual and } \\
\text { mutually beneficial goals. }\end{array}$ & $\begin{array}{l}\text { Cai, Huang, } \\
\text { Liu, \& Liang } \\
\quad(2016)\end{array}$ \\
\hline $\begin{array}{l}\text { Business } \\
\text { Performance }\end{array}$ & $\begin{array}{l}\text { Performance growth emerges from an aggressive or proactive } \\
\text { competitive proactive step in having a new knowledge base as } \\
\text { measured by Sales growth, market share, number of } \\
\text { employees, profitability, profit margin sales, and ability to } \\
\text { fund growth from profit. }\end{array}$ & $\begin{array}{l}\text { Zacca, Dayan, } \\
\text { \& Ahrens } \\
\text { (2015) }\end{array}$ \\
\hline
\end{tabular}


TABLE 2

Demografhics

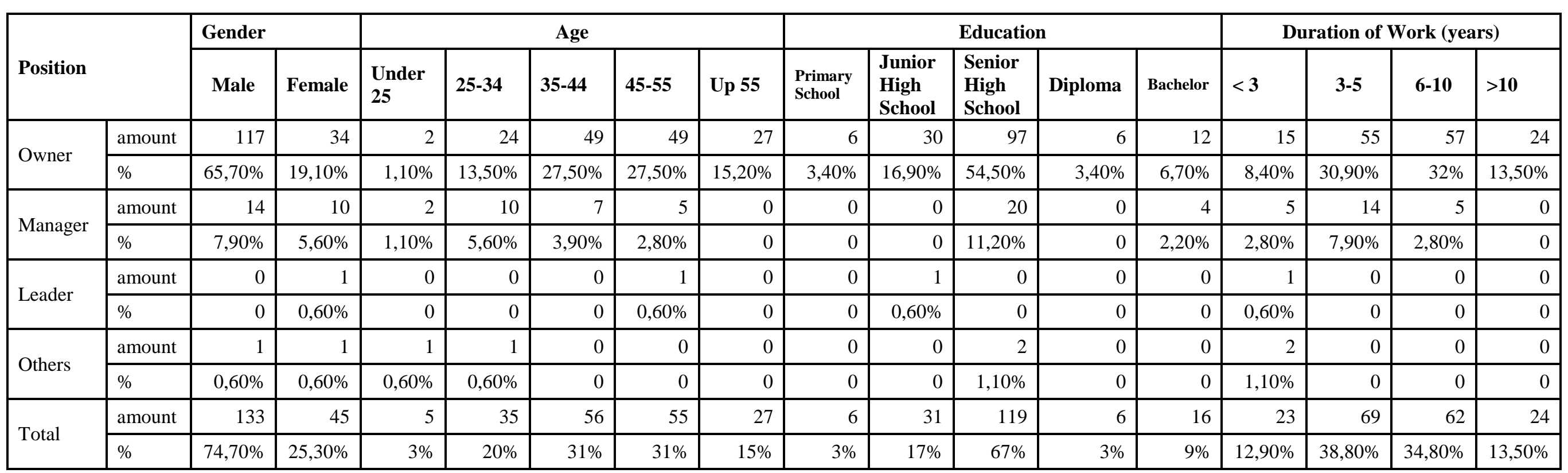

(Continued) 


\section{Descriptive Company Characteristics}

\begin{tabular}{|l|l|r|r|r|r|r|r|r|}
\hline \multirow{2}{*}{ Company Status } & \multicolumn{2}{|c|}{ Length of Operation (Years) } & \multicolumn{3}{|c|}{ Total Employee } \\
\cline { 3 - 9 } & $\mathbf{1 - 5}$ & $\mathbf{6 - 1 0}$ & $\mathbf{1 1 - 2 0}$ & $\mathbf{> 2 0}$ & $<\mathbf{5 - 5 0}$ & $\mathbf{5 1 - 1 0 0}$ \\
\hline \multirow{3}{*}{ UD } & amount & 1 & 6 & 2 & 3 & 0 & 6 & 0 \\
\cline { 2 - 9 } & $\%$ & $0,60 \%$ & $3,40 \%$ & $1,10 \%$ & $1,70 \%$ & 0 & $3,40 \%$ & 0 \\
\hline \multirow{3}{*}{ CV } & amount & 1 & 4 & 0 & 0 & 0 & 5 & 0 \\
\cline { 2 - 9 } & $\%$ & $0,60 \%$ & $2,20 \%$ & 0 & 0 & 0 & $2.8 \%$ & 0 \\
\hline \multirow{3}{*}{ Others } & amount & 73 & 68 & 20 & 0 & 110 & 56 & 1 \\
\cline { 2 - 9 } & $\%$ & $41 \%$ & $38,20 \%$ & $11,20 \%$ & 0 & $61,80 \%$ & $31,50 \%$ & $0,60 \%$ \\
\hline \multirow{3}{*}{ Total } & amount & 75 & 78 & 22 & 3 & 110 & 67 & 1 \\
\cline { 2 - 9 } & $\%$ & $42,10 \%$ & $43,80 \%$ & $12,40 \%$ & $1,70 \%$ & $61,80 \%$ & $37,60 \%$ & $0,60 \%$ \\
\hline
\end{tabular}

The Use of Social Media Types

\begin{tabular}{|r|r|r|r|r|r|}
\hline \multicolumn{5}{|c|}{ Social Media Type } & \multicolumn{2}{l}{ Total } \\
\hline Facebook & Whatsapp & BlackBerryMessenger & \multicolumn{1}{l|}{ LINE } & \multicolumn{1}{l|}{ Others } & \\
\hline 86 & 31 & 35 & 9 & 17 & 178 \\
\hline $48 \%$ & $17 \%$ & $20 \%$ & $5 \%$ & $10 \%$ & $100 \%$ \\
\hline
\end{tabular}

Company Business Type

\begin{tabular}{|c|c|}
\hline \multicolumn{2}{|c}{ Company Business Type } \\
Type of Business & Total \\
\hline \multirow{2}{*}{ Construction } & 18 \\
\cline { 2 - 2 } Finance, rent and service & $10,10 \%$ \\
\cline { 2 - 2 } Trade, Hotel and Restaurant & $19,10 \%$ \\
\cline { 2 - 2 } & $48,90 \%$ \\
\hline \multirow{2}{*}{ Manufacture } & 13 \\
\cline { 2 - 2 } & $7,30 \%$ \\
\hline \multirow{2}{*}{ Electronic, Gas and Water Supply } & 3 \\
\cline { 2 - 2 } & $1,70 \%$ \\
\hline \multirow{2}{*}{ Agriculture } & 4 \\
\cline { 2 - 2 } Handmade & $2,20 \%$ \\
\hline \multirow{2}{*}{ Transport and communication } & 18 \\
\cline { 2 - 2 } & $10,10 \%$ \\
\hline \multirow{2}{*}{ Total } & $0,60 \%$ \\
\hline \multirow{2}{*}{ Han } & 178 \\
\cline { 2 - 2 } & $100 \%$ \\
\hline
\end{tabular}


TABLE 3

Construct Reliability, Variance Extract, Discriminant Validity

\begin{tabular}{|c|c|c|c|c|c|c|}
\hline Indicator & $\begin{array}{r}\text { Loading } \\
\text { Factor }\end{array}$ & $\begin{array}{r}\text { (Loading } \\
{\text { Factor })^{2}}^{2}\end{array}$ & $\begin{array}{r}1 \text { - } \\
\text { (Loading } \\
\text { Factor) }\end{array}$ & $\begin{array}{l}\text { Construct } \\
\text { Reliability }\end{array}$ & $\begin{array}{r}\text { Variance } \\
\text { Extracted }\end{array}$ & $\begin{array}{r}\text { Discriminant } \\
\text { Validity }\end{array}$ \\
\hline \multicolumn{4}{|c|}{ 1. Market Knowledge } & \multirow{5}{*}{0,815} & \multirow{5}{*}{0,525} & \multirow{5}{*}{0,724} \\
\hline MK1 & 0,703 & 0,494 & 0,506 & & & \\
\hline MK2 & 0,719 & 0,517 & 0,583 & & & \\
\hline MK3 & 0,711 & 0,506 & 0,494 & & & \\
\hline MK4 & 0,763 & 0,582 & 0,418 & & & \\
\hline \multicolumn{4}{|c|}{ 2. Customer Engagement } & \multirow{6}{*}{0,893} & \multirow{6}{*}{0,575} & \multirow{6}{*}{0,759} \\
\hline CE5 & 0,716 & 0,513 & 0,487 & & & \\
\hline CE6 & 0,818 & 0,669 & 0,331 & & & \\
\hline CE7 & 0,729 & 0,531 & 0,469 & & & \\
\hline CE8 & 0,767 & 0,588 & 0,412 & & & \\
\hline CE9 & 0,739 & 0,546 & 0,454 & & & \\
\hline \multicolumn{4}{|c|}{ 3. Employee Engagement } & \multirow{10}{*}{0,936} & \multirow{10}{*}{0,561} & \multirow{10}{*}{0,749} \\
\hline EE10 & 0,776 & 0,602 & 0,398 & & & \\
\hline EE11 & 0,721 & 0,520 & 0,480 & & & \\
\hline EE12 & 0,731 & 0,534 & 0,466 & & & \\
\hline EE13 & 0,777 & 0,604 & 0,396 & & & \\
\hline EE14 & 0,757 & 0,573 & 0,427 & & & \\
\hline EE15 & 0,729 & 0,531 & 0,469 & & & \\
\hline EE16 & 0,749 & 0,561 & 0,439 & & & \\
\hline EE17 & 0,722 & 0,521 & 0,479 & & & \\
\hline EE18 & 0,735 & 0,540 & 0,460 & & & \\
\hline \multicolumn{4}{|c|}{ 4. Supply Chain Engagement } & 0,877 & 0,641 & 0,801 \\
\hline
\end{tabular}




\begin{tabular}{|c|c|c|c|c|c|c|}
\hline SCE19 & 0,811 & 0,658 & 0,342 & & & \\
\hline SCE20 & 0,812 & 0,659 & 0,341 & & & \\
\hline SCE21 & 0,816 & 0,666 & 0,334 & & & \\
\hline SCE22 & 0,762 & 0,581 & 0,419 & & & \\
\hline \multicolumn{4}{|c|}{ 5. Business Performance } & \multirow{7}{*}{0,914} & \multirow{7}{*}{0,638} & \multirow{7}{*}{0,799} \\
\hline BP30 & 0,833 & 0,694 & 0,306 & & & \\
\hline BP31 & 0,808 & 0,653 & 0,347 & & & \\
\hline BP32 & 0,797 & 0,635 & 0,365 & & & \\
\hline BP33 & 0,820 & 0,672 & 0,328 & & & \\
\hline BP34 & 0,809 & 0,654 & 0,346 & & & \\
\hline BP35 & 0,722 & 0,521 & 0,479 & & & \\
\hline
\end{tabular}


TABLE 4

Assessment of the Goodness of Fit Research Model

\begin{tabular}{|l|l|r|r|l|}
\hline \multicolumn{1}{|c|}{$\begin{array}{c}\text { Goodness of Fit } \\
\text { Indeks }\end{array}$} & \multicolumn{1}{|c|}{ Cut off Value } & $\begin{array}{r}\text { Default } \\
\text { Model } \\
\text { Results }\end{array}$ & $\begin{array}{r}\text { Secondary } \\
\text { Model } \\
\text { Results }\end{array}$ & \multicolumn{1}{|c|}{$\begin{array}{c}\text { Evaluation } \\
\text { Model }\end{array}$} \\
\hline Chi-Square & Expected small & 410,737 & 399,641 & \multirow{2}{*}{ Fit } \\
\hline Probability & $\leq 0,05$ & 0,008 & 0,017 & \\
\hline GFI & $0,90 \leq$ GFI $<1$ & 0,868 & 0,871 & Marginal Fit \\
\hline RMSEA & $\leq 0,08$ & 0,033 & 0,031 & Close Fit \\
\hline RMR & $\leq 0,05$ & 0,124 & 0,095 & Bad Fit \\
\hline TLI & $0,95 \leq \mathrm{TLI}<1$ & 0,972 & 0,976 & Good Fit \\
\hline NFI & $0,90 \leq \mathrm{NFI}<1$ & 0,865 & 0,868 & Marginal Fit \\
\hline AGFI & $0,90 \leq \mathrm{AGFI}<1$ & 0,844 & 0,847 & Marginal Fit \\
\hline RFI & $0,90 \leq \mathrm{RFI}<1$ & 0,851 & 0,854 & Marginal Fit \\
\hline CFI & $0,95 \leq \mathrm{CFI}<1$ & 0,975 & 0,978 & Good Fit \\
\hline IFI & $0,90 \leq \mathrm{IFI}<1$ & 0,975 & 0,979 & Good Fit \\
\hline Normed Chi- & 2,0 & 1,194 & 1,169 & Good Fit \\
\hline
\end{tabular}


TABLE 5

Structural Equation Modeling Resulth

\begin{tabular}{|c|c|c|c|c|}
\hline \multicolumn{3}{|c|}{ Squared Multiple Correlations } & $\begin{array}{r}\text { Estimate } \\
\text { Defaut Model } \\
\end{array}$ & $\begin{array}{r}\text { Estimate } \\
\text { Secondary Model }\end{array}$ \\
\hline \multicolumn{3}{|l|}{ Employee_Engagement } & ,230 & ,237 \\
\hline \multicolumn{3}{|l|}{ Customer_Engagement } & 149 &, 147 \\
\hline Supply_Chain_Engagement & & & ,440 & 431 \\
\hline \multicolumn{3}{|l|}{ Business_Performance } & ,098 &, 161 \\
\hline \multicolumn{3}{|l|}{$\begin{array}{l}\text { Standardized Regression } \\
\text { Weights }\end{array}$} & $\begin{array}{r}\text { Estimate Defaul } \\
\text { Model }\end{array}$ & $\begin{array}{r}\text { Estimate Secondary } \\
\text { Model }\end{array}$ \\
\hline \multirow{8}{*}{$\begin{array}{l}\text { Employee_Engagement } \\
\text { Customer_Engagement } \\
\text { Supply_Chain_Engagement } \\
\text { Supply_Chain_Engagement } \\
\text { Supply_Chain_Engagement } \\
\text { Business_Performance } \\
\text { Business_Performance } \\
\text { Business_Performance }\end{array}$} & $\begin{array}{ll}<-- \\
\end{array}$ & Market_Knowledge & ,479 & ,487 \\
\hline & $<---$ & Market_Knowledge &, 386 & ,383 \\
\hline & $<---$ & Market_Knowledge &, 216 & ,208 \\
\hline & $<---$ & Customer_Engagement &, 271 & ,279 \\
\hline & $<---$ & Employee_Engagement & 393 & ,383 \\
\hline & $<---$ & Supply_Chain_Engagement & ,313 &, 174 \\
\hline & $<--$ & Customer_Engagement & - &,- 090 \\
\hline & $<--$ & Employee_Engagement & - &, 300 \\
\hline \multicolumn{2}{|l|}{ Regression Weights } & & Estimate S.E. C.R. P & Estimate S.E. $\quad$ C.R. $\quad P$ \\
\hline Employee_Engagement & $\begin{array}{ll}<-- \\
\end{array}$ & Market_Knowledge & $, 659,1265,226 * * *$ & ,666,1265,291 *** \\
\hline Customer_Engagement & $<--$ & Market_Knowledge & ,413,100 4,120 *** & ,408,100 4,084 *** \\
\hline Supply_Chain_Engagement & $<---$ & Market_Knowledge & 286 & 277, 126 2,194, 279 \\
\hline Supply_Chain_Engagement & $<---$ & Customer_Engagement & ,335, 100 3,342 *** & ,348, 101 3,432 *** \\
\hline Supply_Chain_Engagement & $<---$ & Employee_Engagement & 379, 082 4,622 *** & ,372, 083 4,468 *** \\
\hline Business_Performance & $<---$ & Supply_Chain_Engagement & ,284,076 3,763 *** & 158, 098 1,603, \\
\hline Business_Performance & $<--$ & Customer_Engagement & $\begin{array}{llll}- & - & - & -\end{array}$ & 322 \\
\hline Business_Performance & $<--$ & Employee_Engagement & - & 264, 086 3,061,002 \\
\hline
\end{tabular}




\section{FIGURE 2}

\section{Structural Model Estimation}

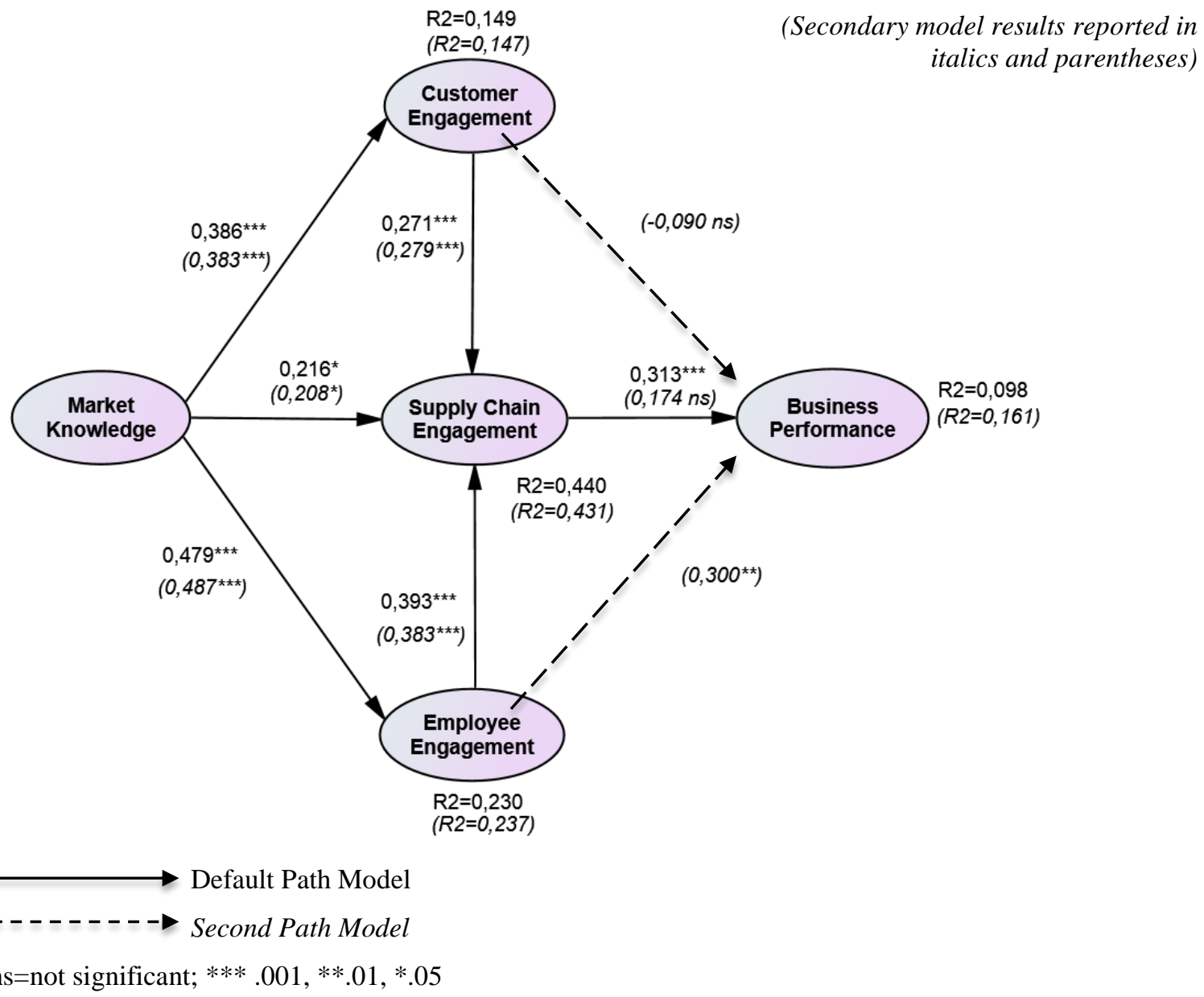

